Michaela Kreyenfeld \& Valerie Martin

\title{
Introduction to the special issue on The dynamics of stepfamilies in cross-national perspective
}

\section{Introduction}

All European countries have seen radical changes in the demographic behavior of their populations in recent decades. Many of the facets of recent family changes have been investigated extensively, such as the increase in childlessness, the delay in first-time parenthood, the decline in marriage intensities, and the growing instability of partnerships. Moreover, the changing family structures - especially the increase in single parent families and the spread of non-marital union - have been described and explored using the concepts of de-standardization, pluralization, or the disintegration of the family (NaveHerz 1998; Tyrell 1979). However, the topic of the increase in the number of stepfamilies has not attracted a similar level of attention in discussions on family change. This stands in contrast to the actual significance of stepfamilies, which may be expected to have grown along with the increase in separation rates. Our knowledge on stepfamilies has often come from clinical psychological studies which mostly provide a negative image of stepfamilies, as only families with problems are likely to seek psychological help (Desrosiers et al. 1994). Representative large scale data to analyze the prevalence of stepfamilies are still rare. It is mainly the data from the Family and Fertility Surveys, which were conducted in the beginning of the 1990s, that have been used to investigate the fertility and partnership behavior of stepfamily members in European countries (Vikat et al. 2004; Thomson 2004; Henz/Thomson 2005). There have also been several country-specific studies that have investigated the prevalence and well-being of stepfamilies (VilleneuveGokalp 2000; Bien et al 2002; Martin 2008; Martin/LeBourdais 2008; Steinbach 2008). However, there is hardly any recent cross-national research on stepfamilies in Europe. This special issue seeks to fill parts of this gap.

In devoting a special issue to the topic of stepfamilies, and in arguing that stepfamilies are a quantitatively significant family type, it is important to acknowledge as well that stepfamilies are far from new. Before the decline in mortality rates in Europe during the $19^{\text {th }}$ century, many children lost their parents before they reached maturity. Thus, the death of the mother or the father was a standard trajectory for children to enter a stepfamily. Fairy tales, such as "Hansel and Gretel", "Snow White", or "Cinderella" docu- 
mented the salience of this family type in the past. As stepfamilies were often preceded by the death of the biological parent, the stepparent usually replaced the biological parent. Contemporary stepfamilies differ, however, from the "historical stepfamily" in many dimensions. The major difference between stepfamilies in the past and present is that stepfamilies today are more complex because the biological parent is generally still alive. If the biological parents have joint custody, both will be involved in childrearing. Furthermore, the child might live in two households and maintain contact with both biological parents so that the family network of stepfamilies mostly involves more than one household unit. Stepfamilies are thus embedded in a greater number of different social contexts than nuclear families. This not only makes their family network more complex, it may also present challenges for the everyday organization of family life (MacDonald/Demaries 2002). Cherlin (1978) has labeled stepfamilies an "incomplete institution", citing a lack of norms and rules that could govern the behavior of stepfamily members. While it is possible to dispute this notion, it is generally acknowledged that stepparents usually take over parental responsibilities, even though the relationship between the stepparent and the child is not regulated; and that the stepparent has only very limited legal rights towards the child if the partnership with the biological parent dissolves.

The complexity of stepfamilies also presents challenges for empirical research on the family. A stepfamily is usually defined as a couple who co-reside with children from prior partnerships (Bumpass et al. 1995; Bien et al. 2002). If children are moving back and forth between the households of their biological parents, this causes problems for research that uses the household unit as a point of reference (Feldhaus/Huinink 2011). Stepfamilies are neither a homogeneous group. They may be distinguished based on whether they are centered around the father or the mother. If only the father has prior children, it is a "stepmother family"; while if only the mother has prior children, it is a "stepfather family" (Ambert 1986; Desrosiers et al. 1995). If the couple has common children, the family is usually titled a "complex family" or a "blended family". There are also very divergent pathways of leading into a stepfamily as it may be various events such as the death of a partner, divorce, separation or lone parenthood that precedes entrance into a stepfamily. Becoming a member of a stepfamily may thus involve a series of life course transitions. Understanding the prevalence and significance of stepfamilies therefore involves taking a dynamic view that allows us to conceptualize the trajectories that lead to stepfamily membership.

\section{Contributions in this special issue}

This special issue assembles contributions that mainly take a dynamic perspective on the evolution and development of stepfamilies. The papers explore the trajectories that lead to forming a stepfamily and the quality of the relationships within nuclear and stepfamilies, as well as the economic performance and stability of stepfamilies relative to other types of families. The contributions in this volume address the situations of stepfamilies in several countries in Europe, such as Germany, France, Sweden, and the Russian Federation. A study on Canada and the U.S. is also included. In the following, we provide details of the papers included in the special issue. 
The first contribution is a paper by Michaela Kreyenfeld and Valerie Martin that provides a cross-national overview on the economic conditions of stepfamilies in France, Western Germany, Eastern Germany, and the Russian Federation. Based on data from the first wave of the Generations and Gender Study from the years 2004/05, the paper describes the trajectories that lead to becoming a stepfamily member, and provides an overview of the prevalence of this family type in the four comparison regions. The authors also discuss how welfare state policies govern the choice of living arrangements, and how they determine the economic performance of different types of families. Stepfamilies are in many respects sui generis, as they differ from other families in several dimensions. In all countries, stepfamilies are larger than nuclear families. In terms of other sociodemographic characteristics (such as education and age), stepfamilies do not, however, differ greatly from nuclear families. An exception is in France, where stepfamily members tend to be less educated and have higher rates of unemployment than nuclear family members. The major finding of this paper is that the socio-demographic differences between the family types can account for the differences in economic well-being between nuclear and stepfamilies in France. However, in Western Germany, stepfamilies seem to fare worse than nuclear families, even after controlling for the socioeconomic composition of the different types of families. In the Russian Federation and Eastern Germany, no differences in economic well-being are discernible between stepfamilies and nuclear families. In these regions, the dividing line with respect to economic well-being runs between lone parents and other types of families.

The subsequent paper, by Jani Turunen, is a country study that focuses on the trajectories that led to the formation of stepfamilies in Sweden for the period 1970-2000. Unlike the first paper, which uses the family as a unit of observation, this paper takes the child's perspective. Using data from the Swedish Level of Living Study (LNU), it looks at when children experience stepfamily membership in their life course. The children are observed from the moment their biological parents separate until a stepparent enters the household. A major finding of this paper is that there are gender-specific differences in the chances of children of entering a stepfamily. Boys are less likely to enter a stepfamily than girls. When the child gets older, these differences diminish. The author also finds that the longer the parent has been separated, the smaller the child's chances of entering a stepfamily are. However, no differences in the rate of entering a stepfamily by the parent's educational characteristics are found. This does not, however, mean that all children have the same overall chances of becoming a member of a stepfamily. It must be taken into account that the only children who were observed were those who were "at risk of becoming a stepfamily member;" i.e., children whose parents were separated or who had never had a serious partnership. As there is an educational gradient in separation risks in Sweden, children of less-educated parents are at greater risk of entering the pool of those at risk of becoming a stepfamily member. If one conditions on the fact that the parents are separated, however, the parents' educational levels do not appear to influence the chances of becoming a stepfamily member.

The paper by Sebastian Schnettler and Anja Steinbach focuses on the relationship between parents and children. Borrowing from concepts of evolutionary biology, they investigate whether the quality of relationships differs between parents and their biological children, and between stepparents and their stepchildren. The operational definition of the 
relationship quality is a measure that uses the children's assessments of the care they receive from their parents, and the closeness they feel with their parents. The data used in this analysis come from the U.S. National Longitudinal Study of Adolescent Health (Add Health). The great advantage of using this dataset is that it allows the authors to make the family a unit of analysis, and to compare siblings within a family. Using fixed-effects modeling, the parent-child relationships within families are compared in order to identify differences in the relationship quality between parents and their biological children, and between stepparents and their stepchildren. The results of this paper confirm the hypotheses of evolutionary biology, which suggest that biological children will experience greater care and attention from their parents. However, it is also acknowledged that other dimensions which might affect the relationship between stepparents and their stepchildren, especially the role of the biological non-co-residential parent, must be explored further.

After this study on the relationship between family members, the next paper, by Valerie Martin, Céline Le Bourdais, and Évelyne Lapierre-Adamcyk, again takes a dynamic perspective, focusing on the separation rates of stepfamilies. It is well-known that stepfamilies are more fragile than other families. This paper goes beyond previous studies, exploring how separation rates vary by different types of stepfamilies. Using data from the Canadian General Social Survey of 2001, the authors show that the stepfamily type is quite influential in determining the stability of a union. Stepfamilies formed around a stepmother tend to be more stable than those formed around a stepfather. Furthermore, stepfamilies are more prone to separate if the couple lives in a non-marital union than in a marital union. These differences between marital and non-marital unions have remained rather constant over time, despite the fact that the share of non-marital unions has grown radically.

The final paper in this special issue is a contribution (in German) written by Ina Jaschinski. This paper is also a dynamic study, which draws on data from the German Generations and Gender Survey from 2005. By means of event-history modeling, the determinants of re-partnering after divorce are investigated. Although that this study does not exclusively address stepfamilies, it is a valuable contribution for understanding the trajectories that lead to becoming a stepfamily member. The paper reveals that there are no gender differences in re-partnering rates; however, age at divorce has a more negative impact on the chances of re-partnering for women than for men. The author also shows that there is a positive educational gradient in re-partnering rates for both sexes. The age and the number of children have relatively little bearing on re-partnering rates.

The papers in this special issue highlight the importance of taking a dynamic perspective on stepfamilies. They suggest that country variations in the trajectories and wellbeing of stepfamilies exist, and that it is beneficial to explore them further. However, this special issue must leave several questions unresolved. In particular, even though the role of stepfamilies in several European countries and the U.S. and Canada is explored, it is beyond the scope of this special issue to provide a comprehensive cross-national overview of the prevalence, dynamics, and economic performance of stepfamilies. In addition, while the number of stepfamilies is growing, the share of stepfamilies is still small in many countries. Thus, survey-based research quickly runs into problems of small sample sizes. Last but not least, the operational definition of stepfamilies is a matter of concern. The papers brought together in this special issue usually define a stepfamily as a family 
composed of a co-residential couple who live with children from prior partnerships in the same household unit. This narrow definition of the stepfamily does not account for the wider family network of stepfamilies, or for the possibility that children whose parents have separated can alternate between their parents' households. One of the challenges of stepfamily research is to go beyond the household unit, and to integrate the wider family network into the research agenda.

\section{References}

Ambert, A.-M. (1986). Being a stepparent: Live-in and visiting stepchildren. Journal of Marriage and the Family, 48, pp. 795-804.

Bien, W., Hartl, A. \& Teubner, M. (Eds.) (2002). Stieffamilien in Deutschland. Eltern und Kinder zwischen Normalität und Konflikt. Opladen: Leske + Budrich.

Bumpass, L. L., Raley K. R. \& Sweet, J. A. (1995). The changing character of stepfamilies: Implications of cohabitation and nonmarital childbearing. Demography, 32, pp. 425-436.

Cherlin, A. (1978). Remarriage as an incomplete institution. American Journal of Sociology, 84, pp. 634650.

Desrosiers, H., Le Bourdais, C. \& Lehrhaupt, K. (1994). Vivre en famille monoparentale et en famille recomposée: portrait des Canadiennes d'hier et aujourd'hui. INRS-Urbanisation. Études et documents, 67, pp. 1-62.

Desrosiers, H., Le Bourdais, C. \& Laplante, B. (1995). Les dissolutions d'union dans les familles recomposées: L'expérience des femmes canadiennes. Recherches sociographiques, XXXVI, pp. 47-64.

Feldhaus, M. \& Huinink, J. (2011, forthcoming). Multiple Elternschaft. Eine Analyse zur Vielfalt von Elternschaft und Folgepartnerschaften. In: Schwab, D. \& Vaskovics, L. A. (Eds.), Pluralisierung von Elternschaft und Kindschaft. Opladen/Farmington Hills, MI: Verlag Barbara Budrich (Sonderheft 8 der Zeitschrift für Familienforschung/Journal of Family Research).

Henz, U. \& Thomson, E. (2005). Union stability and stepfamily fertility in Austria, Finland, France \& West Germany. European Journal of Population, 21, pp. 3-29.

MacDonald, W. L. \& Demaris, A. (2002). Stepfather-stepchild relationship quality: The stepfather's demand for conformity and the biological father's involvement. Journal of Family Issues, 23, pp. 121-137.

Martin, V. (2008). Stepfamilies in Canada: Numbers, characteristics, stability and childbearing. Montreal: McGill University (Dissertation).

Martin, V. \& Le Bourdais, C. (2008). Stepfamilies in Canada and Germany, a comparison. In: Bien, W. \& Marbach, J. H. (Eds.), Familiale Beziehungen, Familienalltag und soziale Netzwerke [Family relations, everyday life within families, and social networks]. Wiesbaden, VS Verlag für Sozialwissenschaften, pp. 241-278.

Nave-Herz, R. (1998). Die These über den ,Zerfall der Familie‘. In: Friedrichs, J. et al. (Eds.); Die Diagnosefähigkeit der Soziologie. Sonderheft 38 der Kölner Zeitschrift für Soziologie und Sozialpsychologie, pp. 286-315.

Steinbach, A. (2008). Stieffamilien in Deutschland. Ergebnisse des Generations and Gender Survey 2005. Zeitschrift für Bevölkerungswissenschaft, 33, pp. 153-180.

Thomson, E. (2004). Stepfamilies and childbearing desires in Europe. Demographic Research, 3, pp. 116-134.

Tyrell, H. (1979). Ehe und Familie. Institutionalisierung und Deinstitutionalisierung. In: Lüscher K. et al. (Eds.), Die „postmoderne “ Familie. Konstanz, Universitätsverlag, pp. 145-156.

Vikat, A., Thomson, E. \& Prskawetz, A. (2004). Childbearing responsibility and stepfamily fertility in Finland and Austria. European Journal of Population, 20, pp: 1-21.

Villeneuve-Gokalp, C. (2000). The double families of children of separated parents. Population (English Selection), 12, pp. 111-137. 